\title{
Nutrient and Dry Matter Contents of Intensively Managed Cassava Grown on an Ultisol ${ }^{1,2}$
}

\author{
Héber Irizarry and Edmundo Rivera ${ }^{3}$
}

\begin{abstract}
Intensively managed, properly fertilized cassava grown on a typical Ultisol had a total of $204,12,222,86$, and $33 \mathrm{~kg} / \mathrm{ha}$ of $\mathrm{N}, \mathrm{P}, \mathrm{K}, \mathrm{Ca}$, and $\mathrm{Mg}$, respectively, at 10 months of age, and yielded 37.5 metric tons/ha of marketable roots. Leaf contents of about $4.3,0.12,1.8,1.4$, and $0.4 \%$ of $\mathrm{N}, \mathrm{P}, \mathrm{K}, \mathrm{Ca}$, and $\mathrm{Mg}$, respectively, 6 months after planting indicated adequate fertilization.
\end{abstract}

\section{INTRODUCTION}

Root crops contribute a major share of the calories consumed by inhabitants of the humid tropics. From 60 to $80 \%$ of the calories consumed by the population of Africa are derived from these crops (4).

Cassava (Manihot esculenta Crantz) is one of the major food crops of the tropics. It is easily propagated from stem cuttings, tolerates periodic drought, is attacked by few insects or diseases of economic importance, and can produce large quantities of high calorie food per unit of land. Abruña et al. (2) found that cassava is highly tolerant to high soil acidity. Yields of cassava grown on a Corozal clay (Aquic Tropudults) were affected only when the soil $\mathrm{pH}$ dropped below 4.3 and the exchangeable $\mathrm{Al}$ increased above $60 \%$ saturation.

Relatively few fertilizer experiments have been conducted with cassava in Puerto Rico. Fox et al. (3) reported a significant response in yield by cassava of the Llanera cultivar grown on Humatas clay (Typic Tropohumults) to the application of $120 \mathrm{~kg}$ of $\mathrm{N} / \mathrm{ha}$, but found no response to $\mathrm{N}$ applications up to $200 \mathrm{~kg} / \mathrm{ha}$ on Torres clay (Plinthic Palehumults). Samuels (6) tested various rates of $\mathrm{N}, \mathrm{P}$, and $\mathrm{K}$ with cassava growing on Corozal clay. He found a significant response in yield to applications of $49 \mathrm{~kg}$ of $\mathrm{P}$ and $93 \mathrm{~kg}$ of $\mathrm{K} / \mathrm{ha}$, but no response to $\mathrm{N}$ applications.

In Costa Rica, Oelsligle (5) determined total N, P, and K content and dry matter accumulation in the tops and roots of cassava plants grown at three fertilizer levels, none of which affected yields. Nutrient removal totaled 367,41 , and $213 \mathrm{~kg} / \mathrm{ha}$ of $\mathrm{N}, \mathrm{P}$, and $\mathrm{K}$, respectively. Average yields of fresh roots was $43 \mathrm{t} / \mathrm{ha}$.

${ }^{1}$ Manuscript submitted to Editorial Board February 25, 1982.

${ }^{2}$ This paper covers work carried out cooperatively between the Agricultural Research Service, USDA, and the Agricultural Experiment Station, University of Puerto Rico, Rio Piedras, PR.

${ }^{3}$ Research Horticulturist and Agronomist, respectively, Agricultural Research Service, USDA, Rio Piedras, PR. 
The present study determined the monthly and total $\mathrm{N}, \mathrm{P}, \mathrm{K}, \mathrm{Ca}$, and $\mathrm{Mg}$ and the dry-matter contents and yields of cassava grown on a typical Ultisol of the humid region of Puerto Rico with adequate fertilization.

\section{MATERIALS AND METHODS}

The experiment was carried out on Corozal clay, at the Corozal Substation. The soil had a $\mathrm{pH}$ of 6.4 and contained $15 \mathrm{p} / \mathrm{m}$ of available $\mathrm{P}$ (Olsen method) and $0.94,9.5$, and $1.4 \mathrm{meq} / 100 \mathrm{~g}$ of soil of exchangeable $\mathrm{K}, \mathrm{Ca}$, and $\mathrm{Mg}$, respectively.

The field was plowed and harrowed twice and divided into 7.4- $\times 3.7$ m experimental plots, each surrounded by border rows and ditches. Stem cuttings of the Llanera cultivar were planted May 20, 1980, 0.92 apart in ridged rows spaced at $1.22 \mathrm{~m}$, or about 9,000 plants/ha.

Fertilizer rates of 0,500 , and $1,000 \mathrm{~kg} / \mathrm{ha}$ of 10-5-20-3 $\left(\mathrm{N}-\mathrm{P}_{2} \mathrm{O}_{5}-\mathrm{K}_{2} \mathrm{O}\right.$ $\mathrm{MgO}$ ) were tested in a randomized complete block design with four replications. The fertilizer was divided into two equal applications 1 and 4 months after planting.

Starting 3 months after planting, and monthly thereafter, one randomly selected plant from each plot was uprooted, washed, and divided into leaf blades and petioles, stems, and roots. Weights of fresh and ovendry plant parts were determined, and dried samples were ground, passed through a 20-mesh screen, and analyzed for $\mathrm{N}$ by the macro-Kjeldahl method; for $\mathrm{P}$, colorimetrically; for $\mathrm{K}$, by flame photometry; and for $\mathrm{Ca}$ and $\mathrm{Mg}$, by the Versenate method after digestion in nitric-perchloric acid.

Ten months after planting, a $3.7 \times 3.7 \mathrm{~m}$ area in each plot was harvested, and yields of marketable roots were determined.

\section{RESULTS AND DISCUSSION}

Similar yields, averaging $37.5 \mathrm{t} / \mathrm{ha}$ of marketable fresh roots were obtained with all three fertilizer levels. Also, examination of the data revealed no appreciable difference in uptake of the various nutrients at the different fertilizer levels. Values presented in this paper are averages of those obtained with the three fertilizer levels.

Contents of $\mathrm{N}$ and $\mathrm{K}$ were similar, increasing rapidly throughout the growth cycle (table 1, figure 1). Contents of $\mathrm{Ca}$ also increased with age, but at a much lower rate. Contents of $\mathrm{P}$ and $\mathrm{Mg}$ were low and leveled. after about 7 months.

Dry matter in the stems, roots, and whole plant increased steadily with plant age (table 2, figure 2). Dry matter in the leaves declined sharply from 5 to 8 months after planting, and thereafter remained stable. Total dry matter in the plants 10 months after planting was $22,548 \mathrm{~kg} / \mathrm{ha}$; yield of edible fresh roots was $37.5 \mathrm{t} / \mathrm{ha}$. 
At harvest, 10 months after planting, the cassava plants contained $204,12,222,86$, and $33 \mathrm{~kg} / \mathrm{ha}$ of $\mathrm{N}, \mathrm{P}, \mathrm{K}, \mathrm{Ca}$ and $\mathrm{Mg}$, respectively (table 1 ). The values for $\mathrm{N}$ and $\mathrm{P}$ were much lower than those reported by Oelsligle (5) for 10-month old cassava plants in Costa Rica, and the value for $\mathrm{K}$ was similar to that reported by Oelsligle. The Ca-supplying power of most soils is sufficient for optimum cassava production.

The nutrients contained in the cassava plants were equivalent to 204, 27,267 and $55 \mathrm{~kg} / \mathrm{ha}$ of $\mathrm{N}, \mathrm{P}_{2} \mathrm{O}_{5}, \mathrm{~K}_{2} \mathrm{O}$, and $\mathrm{MgO}$, respectively, as expressed in commercial fertilizers (table 3). Long-term experiments conducted by

TABLE 1.-Nutrient contents of cassava plants at different ages

\begin{tabular}{crrrrr}
\hline \multirow{2}{*}{ Months after planting } & \multicolumn{5}{c}{ Nutrient } \\
\cline { 2 - 6 } & $\mathrm{N}$ & $\mathrm{P}$ & $\mathrm{K}$ & $\mathrm{Ca}$ & $\mathrm{Mg}$ \\
\hline 3 & 24 & 1 & $\mathrm{~kg} / \mathrm{ha}$ & & \\
5 & 150 & 9 & 111 & 60 & 21 \\
6 & 157 & 7 & 128 & 65 & 23 \\
7 & 171 & 9 & 158 & 76 & 29 \\
8 & 191 & 9 & 223 & 72 & 27 \\
9 & 201 & 8 & 221 & 78 & 26 \\
10 & 204 & 12 & 222 & 86 & 33 \\
\hline
\end{tabular}

TABLE 2.-Dry matter contents of various parts of cassava plants at different ages

\begin{tabular}{crrrr}
\hline \multirow{2}{*}{$\begin{array}{c}\text { Months after } \\
\text { planting }\end{array}$} & \multicolumn{4}{c}{ Plant part } \\
\cline { 2 - 5 } & Leaves & Stems & \multicolumn{1}{c}{ Roots } & Whole plant \\
\hline 3 & 430 & 181 & $\mathrm{~kg} / \mathrm{ha}$ & \\
5 & 2,525 & 3,514 & 2,444 & 763 \\
6 & 2,135 & 4,101 & 3,031 & 8,483 \\
7 & 1,542 & 7,968 & 4,967 & 9,267 \\
8 & 647 & 8,947 & 7,233 & 14,477 \\
9 & 771 & 9,664 & 10,319 & 16,827 \\
10 & 650 & 10,478 & 11,420 & 20,752 \\
& & & & 22,548 \\
\hline
\end{tabular}

Abruña et al. (1) and Vicente-Chandler et al. (7) with tropical grasses growing in Ultisols and Oxisols indicated that those soils can supply about $80 \mathrm{~kg} /$ ha yearly of both $\mathrm{N}$ and $\mathrm{K}_{2} \mathrm{O}$, and about $20 \mathrm{~kg} /$ ha yearly of $\mathrm{MgO}$. Those amounts are equivalent to $68 \mathrm{~kg}$ of $\mathrm{N}$ and $\mathrm{K}_{2} \mathrm{O}$, and $15 \mathrm{~kg}$ of $\mathrm{MgO} /$ ha over the 10 -month cycle for cassava. It is assumed that no $\mathrm{P}$ is provided by the soil since it has no P-bearing minerals.

On the basis of the data on nutrient uptake, the nutrient-supplying power of the soil, and the assumption that the soil provides no P, optimum yields of cassava should be obtained by applying 136, 27, 199, and $40 \mathrm{~kg} /$ 


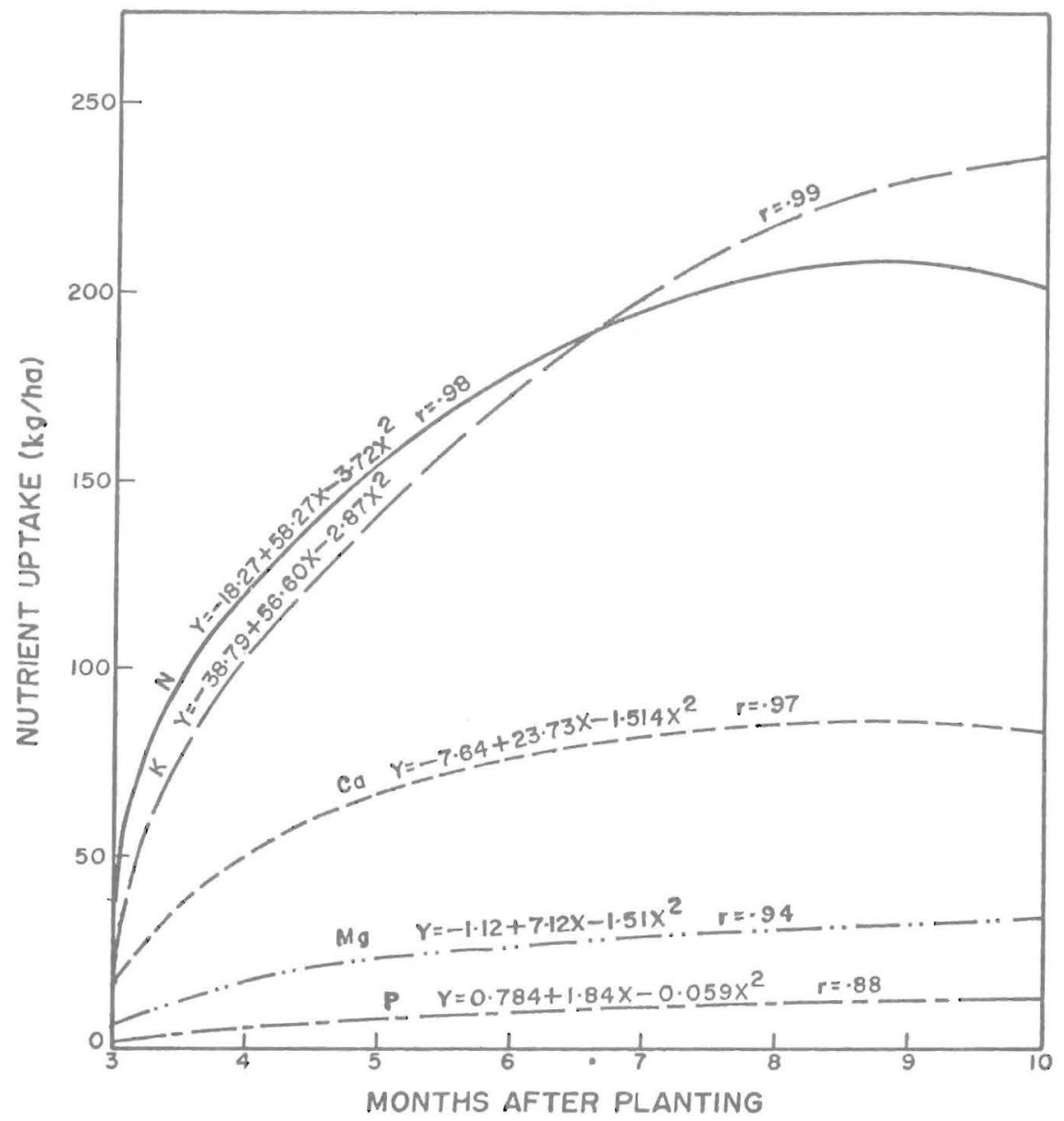

FIG. 1.- Nutrient contents of intensively managed cassava plants grown on a Corozal clay (Ultisol).

ha of $\mathrm{N}, \mathrm{P}_{2} \mathrm{O}_{5}, \mathrm{~K}_{2} \mathrm{O}$, and $\mathrm{MgO}$, respectively. However, Vicente-Chandler et al. (7) reported that about $50 \%$ of the $\mathrm{N}, 20 \%$ of the $\mathrm{P}_{2} \mathrm{O}_{5}$, and $25 \%$ of the $\mathrm{K}_{2} \mathrm{O}$ and $\mathrm{MgO}$ applied as fertilizer is lost. On the basis of those losses, cassava must be fertilized with $272,32,249$, and $50 \mathrm{~kg} / \mathrm{ha}$ of $\mathrm{N}, \mathrm{P}_{2} \mathrm{O}_{5}$, $\mathrm{K}_{2} \mathrm{O}$, and $\mathrm{MgO}$, respectively, roughly equivalent to $2,000 \mathrm{~kg} / \mathrm{ha}$ of $14-2$ 13-3 commercial fertilizer to produce near maximum yields. The fertilizer should be applied in two equal applications, 2 and 6 months after planting.

The data in table 4 indicate that $52,5,110,8$, and $9 \mathrm{~kg} / \mathrm{ha}$ of $\mathrm{N}, \mathrm{P}, \mathrm{K}$, 


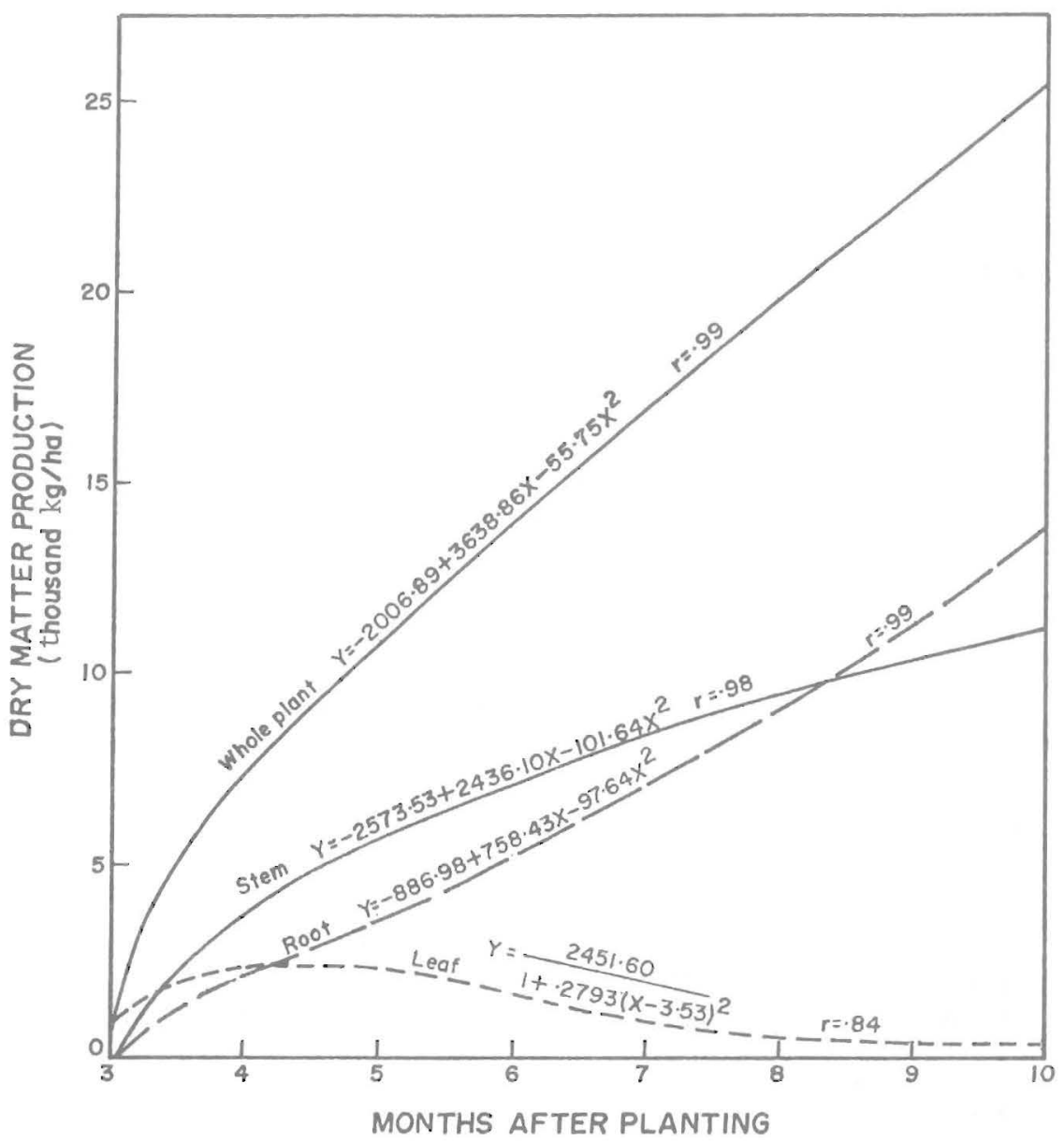

FIG. 2.- Rates of growth by intensively managed cassava plants grown on a Corozal clay (Ultisol).

$\mathrm{Ca}$, and $\mathrm{Mg}$, respectively, amounts contained in $11,420 \mathrm{~kg} / \mathrm{ha}$ of dry matter, were removed from the field in the marketable roots. The other nutrients extracted by the plant are returned to the soil as plant residues and can help reduce fertilizer needs of subsequent crops.

The data in table 5 indicate the changes in nutrient content of different parts of cassava with age of the plants. Nutrient content was considerably higher in the leaves than in the other plant parts at all ages. During the last 3 months, the $\mathrm{N}$ and $\mathrm{K}$ content of the leaves increased, whereas $\mathrm{Ca}$ and $\mathrm{Mg}$ decreased, precisely when the amount of dry matter in the leaves 
decreased (fig. 2, table 2). Phosphorus content remained fairly constant. Contents of $4.3,0.12,1.8,1.4$, and $0.4 \%$ of $\mathrm{N}, \mathrm{P}, \mathrm{K}, \mathrm{Ca}$, and $\mathrm{Mg}$, respectively, in the leaves about 6 months after planting indicated that fertilization was adequate.

After the first few months, the roots enlarged rapidly as they began to store carbohydrates, and their $\mathrm{N}, \mathrm{P}, \mathrm{Ca}$, and $\mathrm{Mg}$ contents decreased, whereas their K content increased (table 5).

TABLE 3,-Computations of fertilizer required by the cassava plant to produce nearmaximum yields

\begin{tabular}{lrrrr}
\hline Nutrient & $\begin{array}{c}\text { Total content of } \\
\text { cassava plants }\end{array}$ & Released by the soil ${ }^{1}$ & $\begin{array}{c}\text { To be supplied from } \\
\text { fertilizer }\end{array}$ & $\begin{array}{c}\text { To be applied as com- } \\
\text { mercial fertilizer }^{2}\end{array}$ \\
\hline & & & $k g / h a$ & \\
$\mathrm{~N}$ & 204 & 68 & 136 & 272 \\
$\mathrm{P}_{2} \mathrm{O}_{5}$ & 27 & 0 & 27 & 32 \\
$\mathrm{~K}_{2} \mathrm{O}$ & 267 & 68 & 199 & 249 \\
$\mathrm{MgO}$ & 55 & 15 & 40 & 50 \\
\hline
\end{tabular}

${ }^{1}$ See text for details.

${ }^{2}$ Assuming losses of $50 \% \mathrm{~N}, 20 \% \mathrm{P}_{2} \mathrm{O}_{5}$, and $25 \% \mathrm{~K}_{2} \mathrm{O}$ and $\mathrm{MgO}$ from the fertilizer applied.

TABLE 4.-Contents of dry matter and nutrients in different parts of the cassava plant

\begin{tabular}{lrrrrrr}
\hline \multirow{2}{*}{ Plant part } & \multicolumn{5}{c}{ Nutrient } & Dry mattex \\
\cline { 2 - 5 } & \multicolumn{1}{c}{$\mathrm{N}$} & $\mathrm{P}$ & $\mathrm{K}$ & $\mathrm{Ca}$ & $\mathrm{Mg}$ & \\
\hline & & & & $\mathrm{kg} / \mathrm{ha}$ & & \\
Leaves & 34 & 2 & 15 & 6 & 2 & 650 \\
Stems & 118 & 5 & 97 & 72 & 22 & 10,478 \\
Total plant residue & 152 & 7 & 112 & 78 & 24 & 11,128 \\
Roots (storage) & 52 & 5 & 110 & 8 & 9 & 11,420 \\
Total & 204 & 12 & 222 & 86 & 33 & 22,548 \\
\hline
\end{tabular}

\section{RESUMEN}

Los contenidos de los nutrimentos nitrógeno, fósforo, potasio, calcio y magnesio por la cultivar de yuca Llanera se determinó en un suelo Corozal arcilloso (Ultisol) a tres niveles de fertilidad. La mitad del abono se aplicó un mes después de la siembra, y el remanente 3 meses más tarde. Los tratamientos se compararon con un diseño de cuatro bloques completos.

Mensualmente, comenzando 3 meses después de la siembra, se cosechó una planta de cada parcela. Esta se dividió en hojas, tallos y raíces, determinándose los pesos verde y seco, y analizándose cada parte para distintos nutrimentos.

Los tres niveles de fertilidad no afectaron la producción de raíces 
TABLE 5.-Nutrient content of leaves, stems, and roots of cassava plants at different ages

\begin{tabular}{|c|c|c|c|c|c|c|c|c|c|c|c|c|c|c|c|}
\hline \multirow{2}{*}{$\begin{array}{l}\text { Age of } \\
\text { plants }\end{array}$} & \multicolumn{5}{|c|}{ Leaves } & \multicolumn{5}{|c|}{ Stems } & \multicolumn{5}{|c|}{ Roots } \\
\hline & $N$ & $\mathrm{P}$ & $\mathrm{K}$ & $\mathrm{Ca}$ & $\mathrm{Mg}$ & $\mathrm{N}$ & $\mathrm{P}$ & $\mathrm{K}$ & $\mathrm{Ca}$ & $\mathrm{Mg}$ & $\bar{N}$ & $\mathrm{P}$ & $\mathrm{K}$ & $\mathrm{Ca}$ & $\mathrm{Mg}$ \\
\hline mo & & & & & & & & $\%$ & & & & & & & \\
\hline 3 & 4.35 & 0.13 & 2.60 & 1.38 & 0.43 & 1.79 & 0.15 & 2.43 & 1.35 & 0.40 & 1.49 & 0.11 & 1.05 & 0.35 & 0.14 \\
\hline 5 & 4.21 & 0.12 & 1.81 & 1.37 & 0.35 & 0.91 & 0.08 & 1.28 & 0.62 & 0.23 & 0.75 & 0.11 & 0.94 & 0.19 & 0.14 \\
\hline 6 & 4.25 & 0.11 & 1.84 & 1.36 & 0.36 & 0.89 & 0.06 & 1.27 & 0.63 & 0.23 & 0.70 & 0.05 & 0.98 & 0.15 & 0.11 \\
\hline 7 & 4.19 & 0.14 & 1.82 & 1.52 & 0.42 & 1.09 & 0.06 & 1.08 & 0.66 & 0.22 & 0.71 & 0.06 & 0.99 & 0.11 & 0.10 \\
\hline 8 & 4.71 & 0.12 & 2.71 & 1.02 & 0.31 & 1.09 & 0.05 & 1.10 & 0.65 & 0.18 & 0.68 & 0.06 & 1.36 & 0.11 & 0.10 \\
\hline 9 & 4.97 & 0.13 & 2.32 & 1.18 & 0.28 & 1.12 & 0.05 & 1.08 & 0.72 & 0.16 & 0.56 & 0.04 & 1.24 & 0.10 & 0.07 \\
\hline 10 & 5.19 & 0.15 & 2.33 & 0.90 & 0.29 & 1.13 & 0.05 & 1.05 & 0.63 & 0.20 & 0.52 & 0.04 & 1.14 & 0.07 & 0.07 \\
\hline
\end{tabular}


comerciales, que fue de 37.5 toneladas métricas/ha a los 10 meses de la siembra.

Las plantas llegaron a contener un máximo de 204, 12, 222, 86, у 33 $\mathrm{kg} / \mathrm{ha}$ de nitrógeno, fósforo, potasio, calcio y magnesio, respectivamente.

Los contenidos de nitrógeno y potasio fueron altos, el de calcio intermedio y los de fósforo y magnesio bajos, durante todo el ciclo de crecimiento.

El contenido de materia seca en los tallos y raíces aumentó con la edad de las plantas, pero el de las hojas bajó señalamente después de los 6 meses, estabilizándose luego de los 8 meses. El contenido de nutrimentos fue siempre mayor en las hojas todo el tiempo.

Cálculos basados en el contenido de nutrimentos en la yuca, la cantidad de los mismos disponibles en suelos Ultisols típicos en Puerto Rico y las pérdidas de nutrimentos aplicados como abono, demuestran que para obtener rendimientos aproximadamente máximos de la yuca es necesario aplicar $272,32,249$, y $50 \mathrm{~kg} / \mathrm{ha}$ de $\mathrm{N}, \mathrm{P}_{2} \mathrm{O}_{5}, \mathrm{~K}_{2} \mathrm{O}$, y $\mathrm{MgO}$, respectivamente, equivalentes a alrededor de 2,000 kg/ha de un abono comercial 14-2-133. Este abono debe aplicarse en dos partes iguales 2 y 6 meses después de la siembra. Los contenidos de $4.3,0.12,1.8,1.4$, y $0.4 \%$ de nitrógeno, fósforo, potasio, calcio y magnesio, respectivamente, en las hojas de yuca indicaron un nivel adecuado de abonamiento.

\section{LITERATURE CITED}

1. Abruña, F., Vicente-Chandler, J., Figarella, J. and Silva, S., 1976. Potassium supplying power of the major Ultisols and Oxisols of Puerto Rico, J. Agric. Univ. P.R. 60 (1): $45-60$.

2. Abruña, F., Vicente-Chandler, J., Rodríguez, J. and Badillo, J., 1982. Effect of soil acidity components on yield and foliar composition of tropical root crops, Soil Sci. Soc. Am. J. 46 (5): 1004-7.

3. Fox, R. H., Talleyrand, H. and Scott, T. W., 1975. Effect of nitrogen fertilization on yields and nitrogen content of cassava, Llanera cultivar, J. Agric. Univ. P.R. 59 (2): 115-24.

4. Johnston, B. F, 1958. The staple food economics of Western Tropical Africa, Stanford University Press, Stanford, California.

5. Oelsligle, D. D., 1975. Accumulation of dry matter, nitrogen, phosphorus, and potassium in cassava (Manihot esculenta, Crantz) Inst. Interam. Cienc. Agric., Turrialba, Costa Rica 25 (1): 85-7.

6. Samuels, G., 1969. The influence of fertilizer levels and sources on cassava production on a Lares clay in Puerto Rico, Caribbean Food Crops Soc. Proc. (MartiniqueGuadeloupe) 7: 33-6.

7. Vicente-Chandler, J., Abruña, F., Caro-Costas, R., Figarella, J., Silva, J., and Pearson, R. W., 1974. Intensive grassland management in the humid tropics of Puerto Rico, Agric. Exp. Stn. Univ. P.R. Bull. 233. 